\title{
Investigation of temperature drop in domestic hot water circuit
}

\author{
Ilona Rzeźnik ${ }^{1, *}$ \\ ${ }^{1}$ Poznan University of Technology, Institute of Environmental Engineering, ul. Berdychowo 4, \\ 61-131 Poznań, Poland
}

\begin{abstract}
The results of experimental investigation of determining the time of temperature drop in domestic hot water circuit were presented in this paper on the example of single-family house. The test were carried out on vertical sections of installations made of $\mathrm{PE}-\mathrm{X} / \mathrm{Al} / \mathrm{PE}$ pipes (crosslinked polyethylene and aluminum) with and without insulation. The temperature drop process was investigated in temperature range typical for domestic hot water installation from $55^{\circ} \mathrm{C}$ to $40^{\circ} \mathrm{C}$. On the basis of the obtained results with appropriate adjustment of the working time of circulation pump, energy savings of $90 \%$ were achieved.
\end{abstract}

\section{Introduction}

In the era of reducing the consumption of natural resources, we are looking it in every area of our life. We can achieve this by reducing energy consumptions in our nearest surrounding - house, workplace. The reducing of energy consumption in buildings led to the invention of the concept of energy-saving and even passive house. Constant improvement of thermal parameters this type of building led to a situation in which operating cost to cover energy demand in domestic hot water (DHW) system exceeded costs related to the operation of the heating installation. Consumption of primary energy in the buildings is $59 \%$ for domestic hot water (DHW), heating and ventilation $28 \%$, and other auxiliary equipment 13\% [9]. Determining the amount of heat loss and the related operating costs of domestic hot water system is therefore very important in the overall heat balance of a single-family house [7], and that's why in this paper the search for possibilities to reduce energy consumption in a domestic hot water installation was undertaken.

One of the ways to reduce energy consumption for domestic hot water is using of phase change materials [1] or renewable energy sources: sun [2, 10], ground [3]. In the literature, we can also find proposals for adjusting the heating installation to reduce energy consumption $[4,5,8]$.

In order to ensure the comfort of a constant supply of hot water at each water pickup point in the building, water circulation, enforced by a circulating pump, is used. To reduce operating costs, the pump is switched off temporarily (ON/OFF regulation is employed). The pump shutdown time is directly related to the nature of the building and the intensity of using hot water in it. Most often, the time of shutting down the pump takes place at night

\footnotetext{
*Corresponding author: ilona.rzeznik@put.poznan.pl
} 
and in public or office buildings outside the hours of people staying in them, and in singlefamily homes outside the residence hours of the household members.

The work presents a proposal to control the circulation pump's working time depending on the temperature drop of domestic hot water.

\section{Experimental procedure}

\subsection{Assumptions for research}

In Poland obligation of designing circulation in domestic hot water installation in buildings results from the Regulation of the Minister of Infrastructure regarding technical conditions for buildings and their location [6]. Its correct design and implementations let the occupants use water at the right temperature after a time of not more than a few seconds, not depending on distance between water pickup point and preparation point of hot water. According to recalled Regulation, the temperature of domestic hot water in water pickup point can't be higher than $60^{\circ} \mathrm{C}$ and lower than $55^{\circ} \mathrm{C}$. Additionally it was established that the occupant will not feel reduce of comfort if in the beginning of water pickup it will have the temperature at the level of $40^{\circ} \mathrm{C}$. According to this it was established that during experiments the process of water temperature drop will be from $55^{\circ} \mathrm{C}$ to $40^{\circ} \mathrm{C}$.

\subsection{Experimental stand}

In Fig. 1 the diagram of experimental stand has been shown and in Fig. 2 has been shown its photo. The measuring section has been modeled out of the pipe which currently is most often used in the installation of domestic hot water in single-family house - PE-X/Al/PE, i.e. a multilayer pipe made of cross-linked polyethylene and aluminum, with diameter of $16 \times 2$. In addition, the tests were repeated using a $9 \mathrm{~mm}$ thick polyurethane foam insulation.

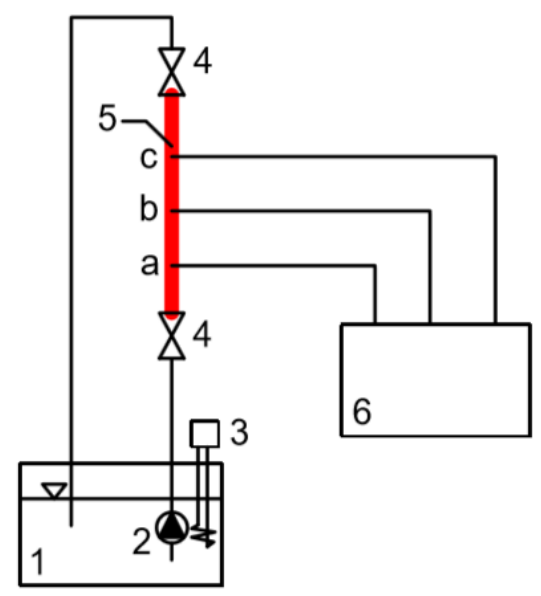

Fig. 1. The diagram of experimental stand, 1-ultratermostat, 2-circulation pump, 3-thermometer, 4shut-off valves, 5-measuring section ( $\mathrm{a}, \mathrm{b}, \mathrm{c}$ - place of connecting thermocouples), 6-Omega RDMV100 recorder. 


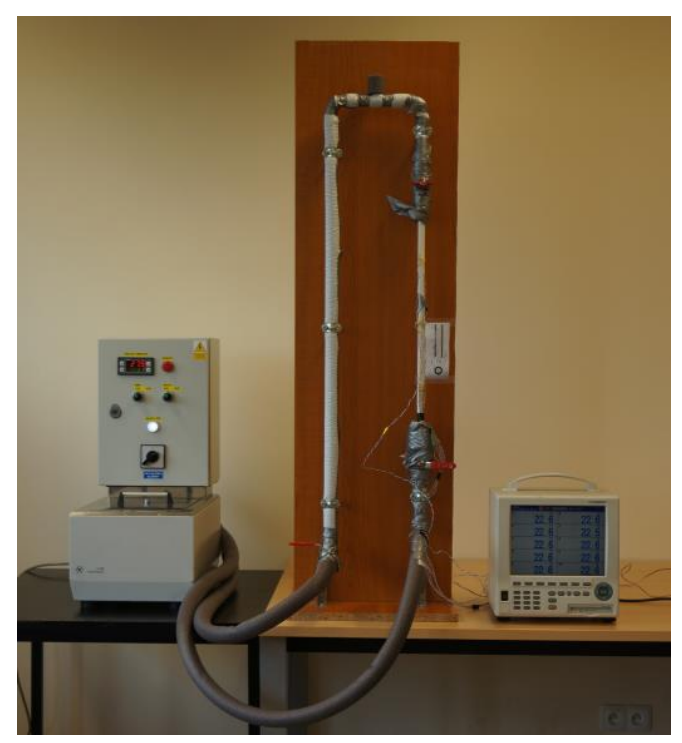

Fig. 2. The photo of measuring stand.

In Fig. 3 the thermocouples way of deployment has been shown. Thermocouples number 1, 4, 7 have been placed in the tube axis, thermocouples number 2, 5, 8 on the inside of pipe wall, thermocouples number $3,6,9$ on the outside of pipe wall. When the pipe was insulated in the place between pipe and insulation thermocouple number 10 was located. Thermocouple number 11 measured the temperature of air in the room.
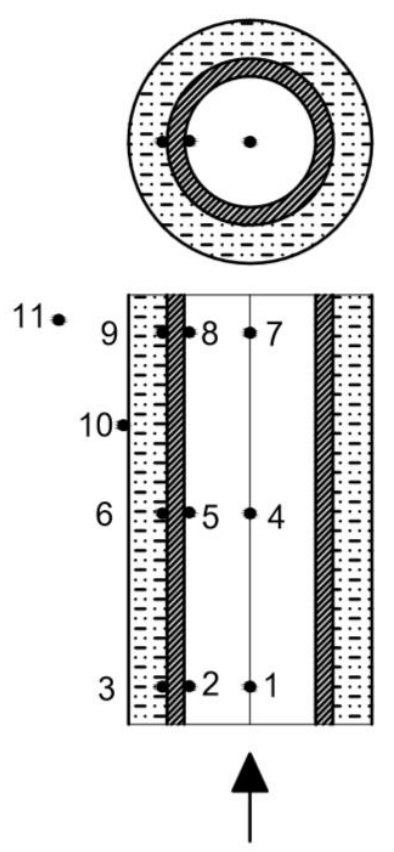

Fig. 3. Location of thermocouples. 


\section{Results}

The tests were carried out in laboratory conditions, in the area of Poznan University of Technology in August 2017. Two measured series were made with measuring section:

- insulated PE-X/A1/PE pipe,

- not insulated PE-X/Al/PE pipe.

Each of series was repeat 10 times. Results of measurements were shown in the Table 1 below. The air temperature in the laboratory during tests hesitated within limits from $22.7^{\circ} \mathrm{C}$ to $24.1^{\circ} \mathrm{C}$, with relative humidity of $59 \%$. The time of temperature drop and the temperature drop was monitored by Omega RD-MV100 recorder with a two-second step. The beginning of measurement was assumed at the moment when all thermocouples placed in the tube axis (number 1, 4 and 7) indicated temperature $55^{\circ} \mathrm{C}$ (then the valves have been closed and in measuring section the water did not flow), and the end when temperature in these places decreased below $40^{\circ} \mathrm{C}$. The pump was switched off when the temperature reached the set value and started to work (and the valves have been opened) when the measuring series was completed.

Table 1. The time of water temperature drop in hot utility water installation.

\begin{tabular}{|c|c|c|}
\hline Type of pipe & $\begin{array}{c}\text { Average time } \\
\text { of water } \\
\text { temperature } \\
\text { drop [s] }\end{array}$ & $\pm[\mathbf{\%}]$ \\
\hline Insulated PE-X/A1/PE & 1488.8 & 5.21 \\
\hline $\mathrm{PE}-\mathrm{X} / \mathrm{Al} / \mathrm{PE}$ & 775.6 & 2.47 \\
\hline
\end{tabular}

The exemplary process of water temperature drop in insulated PE-X/Al/PE pipe during one of the measurement series is shown in fig. 4. As can be seen, the water temperature drop is the first-order response.

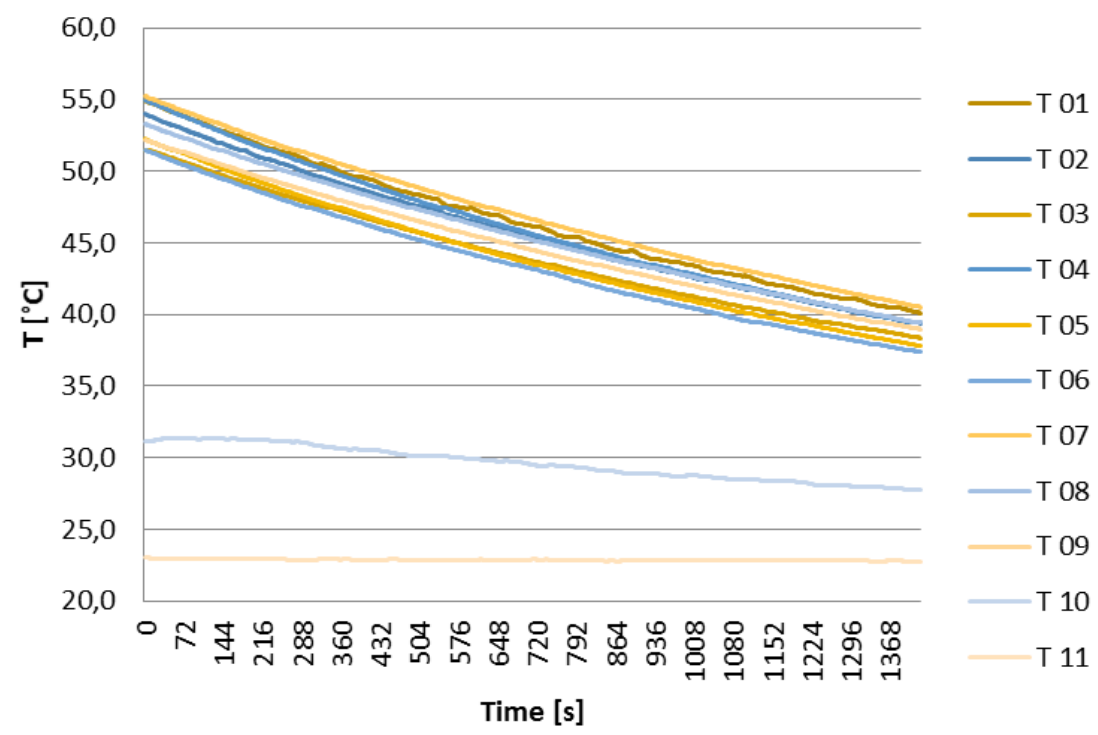

Fig. 4. An exemplary process of water temperature drop in insulated $\mathrm{PE}-\mathrm{X} / \mathrm{Al} / \mathrm{PE}$ pipe. 
The comparison of water temperature drop in both types of pipes for averaged temperature values has been shown in Fig. 5.

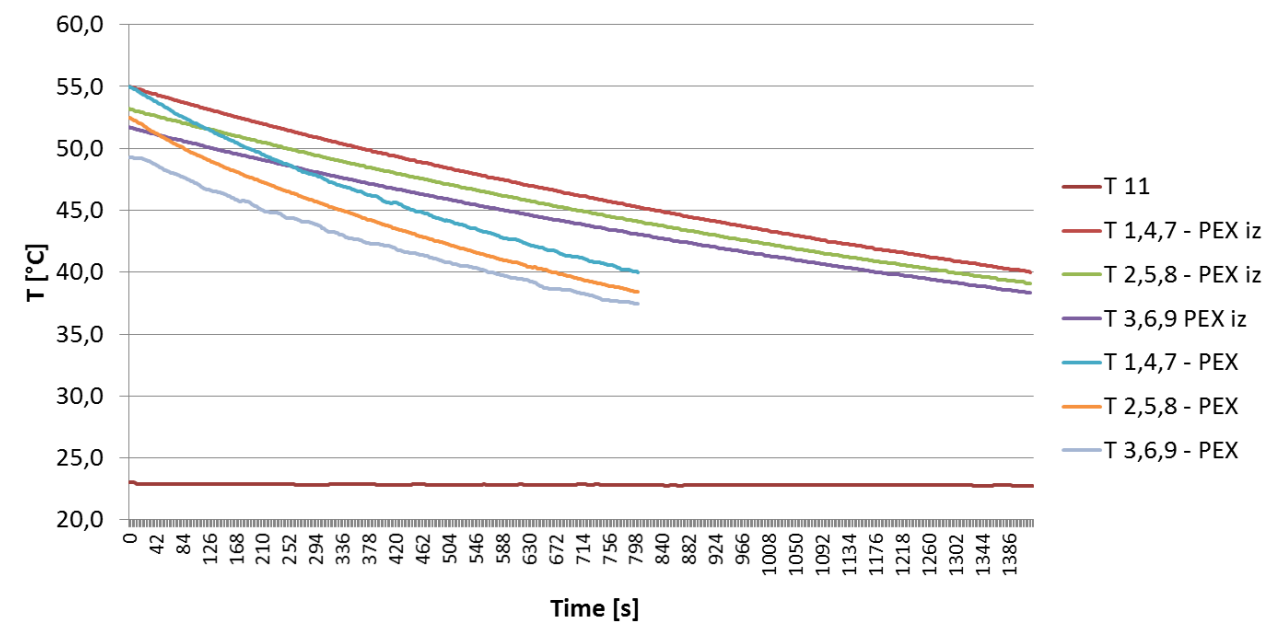

Fig. 5. The comparison of water temperature drop in both types of pipes.

As can be seen from the measurements, insulating the pipe extended the water temperature drop almost twice.

\section{Hot water regulation}

Based on the results obtained during this study 2 variants of hot water flow control were proposed in the single-family residential building. The distance from the boiler that heats up the hot utility water to the farthest outlying point has been assumed to be typical in this type of buildings $10 \mathrm{~m}$. According to the assumptions of the standard PN-92/B-01706 speed of water flow rate in circulating installation is in the range of $0.2-0.5 \mathrm{~m} / \mathrm{s}(\max 1.0 \mathrm{~m} / \mathrm{s})$. Assuming a speed of $0.5 \mathrm{~m} / \mathrm{s}$, hot water will be supplied from the source to the farthest pickup point in $20 \mathrm{~s}$. Temperature drop from $55^{\circ} \mathrm{C}$ to $40^{\circ} \mathrm{C}$ was assumed after rounding the values at a safe level that does not allow to lower the water temperature below the set value of $40^{\circ} \mathrm{C}$ :

- for insulated $\mathrm{PEX} / \mathrm{Al} / \mathrm{PE}$ pipe $-1400 \mathrm{~s}$

- for $\mathrm{PEX} / \mathrm{Al} / \mathrm{PE}$ pipe $-700 \mathrm{~s}$.

The analysis was submitted:

Variant 0 - continuous operation time of the circulation pump.

Variant 1 - temporary shutting down of the pump, maintaining continuous comfort of supplying hot water in the range from $55^{\circ} \mathrm{C}$ to $40^{\circ} \mathrm{C}$. When temperature falls below $40^{\circ} \mathrm{C}$ the circulation pump is activated and operates $100 \mathrm{~s}$, which allows to supply of water at $55^{\circ} \mathrm{C}$ to the farthest pickup point.

Variant 2 - temporary shutting down of the pump according to the time of people's residence, or the use of the installation. In the case of a single-family home - from 9.00 to 15.00 pump completely turned off, from 15.00 to 9.00 pump operation while maintain the comfort of hot water in the range from $55^{\circ} \mathrm{C}$ to $40^{\circ} \mathrm{C}$.

The operating time of the circulation pump for subsequent variants is presented in the Table 2 below. 
Table 2. Daily working time and number of cycles of the circulating pump for the assumed variants.

\begin{tabular}{|c|c|c|c|c|c|}
\hline \multirow{2}{*}{ Type of pipe } & $\begin{array}{c}\text { Variant 0 } \\
\text { [s/day] }\end{array}$ & $\begin{array}{c}\text { Variant 1 } \\
\text { [s/day]/ } \\
\text { Number of } \\
\text { cycles }\end{array}$ & $\begin{array}{c}\text { Variant 2 } \\
\text { [s/day]/ } \\
\text { Number of } \\
\text { cycles }\end{array}$ & $\begin{array}{c}\text { Savings of } \\
\text { energy } \\
\text { consumption } \\
\text { variant 1 [\%] }\end{array}$ & $\begin{array}{c}\text { Savings of } \\
\text { energy } \\
\text { consumption } \\
\text { variant 2 [\%] }\end{array}$ \\
\cline { 1 - 5 } $\begin{array}{c}\text { Insulated } \\
\text { PEX/A1/PE }\end{array}$ & \multirow{2}{*}{$\mathbf{8 6 4 0 0 s / d a y ~}$} & $6600 / \mathbf{5 7}$ & $4400 / \mathbf{4 3}$ & 92.36 & 94.91 \\
\cline { 1 - 3 } $\mathrm{PEX} / \mathrm{Al} / \mathrm{PE}$ & & $10800 / \mathbf{1 0 8}$ & $8100 / \mathbf{8 1}$ & 87.50 & 90.63 \\
\hline
\end{tabular}

\section{Conclusions}

Based on the conducted analysis, it was found that with proper adjustment of the circulation pump, it is possible to limit the power consumption from $87.50 \%$ (non-insulated pipe) to even $94.91 \%$ (insulated pipe) under appropriate conditions, maintaining thermal comfort of water in the temperature range from $55^{\circ} \mathrm{C}$ to $40^{\circ} \mathrm{C}$ at each pickup point. Unfortunately, this is associated with frequent switching on and off of the pump up to more than 100 times a day (in case with non-insulated pipes). The pipe insulation allows to reduce the number of pump cycles by up to half by doubling the time of temperature drop of the installation water.

A typical circulating pump installed in single-family residential buildings has a power of $0.1 \mathrm{~kW}$, which results in consumption of electrical power at the level of $876 \mathrm{kWh}$ per year. With the average price in Poland for $1 \mathrm{kWh}$ of electricity at the level of 0.55 PLN, the annual cost of energy consumption by a circulation pump in a single-family home is 481.8 PLN. With the potential calculated $90 \%$ savings, the annual operating cost decreases to 48.2 PLN. With the average price of such pump at 300 PLN, its cost is already payable in the first year of application of the regulation.

By limiting the number of ON/OFF cycles to one every hour ( 24 cycles a day), assuming a continuous water supply within the assumed temperature range, we will achieve savings of $38.9 \%$ for insulated $\mathrm{PEX} / \mathrm{Al} / \mathrm{PE}$ pipe and $19.4 \%$ for non-insulated pipe.

Experimental tests were carried out at ambient temperatures in the range from $22.7^{\circ} \mathrm{C}$ to $24.1^{\circ} \mathrm{C}$. In further research, it would be necessary to measure the temperature drop of the installation water at other outside temperatures, ore for the horizontal pipes and when embedding an element in the wall.

As you can see by introducing small changes, in a proper way regulating everyday devices, we can achieve large savings without significantly reducing our comfort of living.

\section{References}

1. M.K. AnuarSharif, A.A. Al-Abidi, S. Mat, K. Sopian, M.H. Fuslan, M.Y. Sulaiman, M.A.M. Rosli, Renewable and Sustainable Energy Reviews 42 (2015)

2. J. L. Duomarco, Solar Energy 111 (2015)

3. C. Montaqud, J.M. Corbera, A. Montero, Energy and Buildings 68 (2014)

4. J. Nejranowski, W. Szaflik, COW 39, 12 (2008)

5. A. Pleśniarska, S. Englart, J. Jeżowiecki, Rynek Instalacyjny 6 (2004)

6. Rozporządzenie Ministra Infrastruktury $\mathrm{z}$ dnia 12 kwietnia 2002r. w sprawie warunków technicznych, jakim powinny odpowiadać budynki i ich usytuowanie (Dz. U. Nr 75/2002, poz. 690, z późniejszymi zmianami)

7. W. Szaflik, Instal 2 (2002) 
8. R. Śnieżyk, Rynek Insalacyjny 5 (2014)

9. A. Trząski, Rynek Instalacyjny 10 (2015)

10. N.T. Uday Kumar, G. Mohan, A. Martin, Applied Energy 170 (2016) 